\title{
ANALISIS KESALAHAN BERBAHASA INDONESIA DI SEKOLAH DASAR
}

\section{Marwan Pandeangan, Jangkontua Siburian, Livia Olga Indah Sari, Novita Sari} Surel: marwan130497@gmail.com

\begin{abstract}
This study aims to describe the mistakes in Indonesian language made by students in elementary schools in general. The focus of the study was conducted on language errors in writing skills in elementary school. This type of research is descriptive research. The data source in this research is searching relevant journals. The analysis technique used in analyzing language errors is qualitative data analysis techniques. The results showed that there were student errors in writing including: spelling mistakes (errors in writing basic words, mistakes in using capital letters, mistakes in writing prefixes, mistakes in writing prepositions, mistakes in abbreviated writing, and errors in punctuation), errors in word selection (use of words speech), and mistakes in sentence construction (incomplete sentences, ineffective sentences, and sentences containing interference). Thus, students 'mistakes in writing must be minimized as an effort to improve students' writing skills in elementary school.
\end{abstract}

Keywords: Language errors, spelling, word selection, sentence organization

\begin{abstract}
ABSTRAK
Penelitian ini bertujuan untuk mendeskripsikan kesalahan berbahasa Indonesia yang dilakukan siswa di Sekolah Dasar (SD) secara umum. Fokus penelitian dilakukan pada kesalahan berbahasa pada keterampilan menulis di SD. Jenis penelitian ini adalah penelitian deskriptif. Sumber data dalam penelitian ini adalah penelusuran jurnal-jurnal yang relevan. Teknik analisis yang digunakan dalam menganalisis data kesalahan berbahasa yakni teknik analisis data kualitatif. Hasil penelitian menunjukkan bahwa terdapat kesalahan siswa dalam tulisan meliputi: kesalahan pemakaian ejaan (kesalahan penulisan kata dasar, kesalahan pemakaian huruf kapital, kesalahan penulisan awalan, kesalahan penulisan preposisi, kesalahan penulisan singkatan, dan kesalahan pemakaian tanda baca), kesalahan pemilihan kata (penggunaan kata tutur), dan kesalahan penyusunan kalimat (kalimat tidak lengkap, kalimat tidak hemat, dan kalimat mengandung interferensi). Dengan demikian, kesalahan siswa dalam menulis harus dapat diminimalisir sebagai upaya meningkatkan keterampilan menulis siswa di SD.
\end{abstract}

Kata Kunci: Kesalahan Berbahasa, Pemilihan Kata, Penyusunan Kalimat

\section{PENDAHULUAN}

Bahasa Indonesia adalah bahasa nasional sebagai pemersatu bangsa. Melalui bahasa Indonesia komunikasi dapat terjalin dengan banyaknya bahasa-bahasa daerah yang ada di Indonesia. Dalam kehidupan sehari-hari bahasa Indonesia sendiri berbeda-beda pengucapannya tergantung dialek yang mengungkapkannya, seperti orang batak akan memiliki ciri khas sendiri jika dibandingkan dengan orang jawa yang terkesan lembut. 
Dengan keragaman kebudayaan khususnya bahasa yang beraneka ragam, turut serta mempengaruhi kemampuan berbahasa Indonesia. Keadaan ini disebabkan orang Indonesia mengenal dan menguasai lebih dari satu bahasa. Mereka setidaknya mengenal bahasa daerah dan bahasa Indonesia. Hal ini tentu tidak menutup kemungkinan munculnya kesalahan berbahasa Indonesia yang diakibatkan oleh adanya pengaruh bahasa daerah terhadap bahasa Indonesia.

Sebagai bahasa nasional atau bahasa utama, bahasa Indonesia menjadi mata pelajaran wajib di setiap jenjang persekolahan mulai dari Sekolah Dasar (SD) hingga perguruan tinggi. Johnson (1981) menyatakan bahwa pembelajaran bahasa pada hakikatnya bertujuan memberikan kompetensi komunikatif kepada pembelajar. Selanjutnya, Brown (2000:247) menjelaskan bahwa kompetensi komunikatif meliputi kompetensi: (1) gramatikal, (2) kewacanaan, (3) sosiolinguistik, dan (4) strategi. Pembelajar bahasa dikatakan memiliki kompetensi komunikatif jika telah memiliki keempat kompetensi tersebut. Kompetensi komunikatif menekankan kegramatikalan dan ketepatan konteks (Suparnis, 2007:9). Sejalan dengan ini, Nurgiyantoro (2010:326) menyatakan bahwa kompetensi kebahasaan yang terpenting yang sangat dibutuhkan dalam kinerja berbahasa adalah struktur tata bahasa dan kosakata. Pentingnya kompetensi gramatikal juga tersirat pada ungkapan Canale (1980:6) yang menyatakan bahwa kempetensi berkaitan dengan kode bahasa yang meliputi cirri-ciri dan kaidah-kaidah bahasa.

Permasalahan yang paling banyak ditemukan dalam pembelajaran aspek kebahasaan di sekolah adalah pembelajaran itu mengacu pada materi kebahasaan dalam buku pelajaran. Hal itu terjadi karena keterbatasan guru dan anggapan mereka bahwa bahan yang disediakan sesuai dengan prinsipprinsip dan cara belajar bahasa. Padahal kenyataan menunjukkan bahwa banyak buku pelajaran yang menyajikan aspek kebahasaan yang tidak sesuai dengan kurikulum. Tingkat relevansi aspek kebahasaan dalam buku ajar dengan Kurikulum 2013 sangat rendah (Faisal, 2017;2018;2019;2020).

Kenyataan tersebut dapat menimbulkan kekhawatiran pada peneliti akan punahnya bahasa Indonesia terutama bahasa Indonesia standar (Ghufron, 2009:72). Untuk mengatasi problema tersebut, solusi yang dapat diambil di antaranya menyusun buku ajar kebahasaan berdasarkan kesalahan berbahasa siswa. Sebagai langkah awal, perlu dilakukan penelitian tentang kesalahan berbahasa siswa. Berdasarkan uraian tersebut, penelitian tentang kesalahan berbahasa siswa ini sangat urgen untuk dilakukan.

Alasan utama pentingnya dilakukan penelitian ini adalah hipotesis masukan yang sangat 
memperhatikan kompetensi siswa dan teori behaviorisme Skinner yang menyatakan bahwa penguasaan bahasa pada hakikatnya merupakan suatu proses pembentukan kebiasaan yang dapat terjadi melalui penguatan positif atau negatif. Dengan ditunjukkan kesalahan berbahasa ini dilanjutkan dengan pembetulan kesalahan, siswa dibiasakan membetulkan bentuk-bentuk bahasa yang salah sehingga tidak akan menggunakan bentuk salah tersebut bahkan akan mampu menunjukkan dan menggunakan bentuk-bentuk yang benar. Pada sisi lain, pembelajaran bahasa Indonesia selama ini masih belum memuaskan. Yang dijadikan tumpuan kesalahan adalah jenjang pendidikan SD. Karena itu, penelitian ini memilih jenjang SD dengan pertimbangan bahwa ibarat bangunan gedung, pendidikan pada jenjang ini merupakan fondasi bangunan. Apabila fondasinya kokoh, terbuka kemungkinan besar untuk mengembangkan bangunan yang kuat di atasnya (Sumardi, 2000:1).

\section{METODE PENELITIAN}

Penelitian ini dirancang dalam penelitian deskriptif kualitatif dengan subjek penelitian siswa SD. Untuk mengumpulkan data penelitian digunakan teknik tes, teknik simak, dan teknik catat. Teknik tes digunakan dengan cara memberikan tes tertulis kepada siswa yang berupa tes mengarang. Adapun materi tes tersebut dibatasi pada standar kompetensi menulis yang menuntut penggunaan bahasa Indonesia yang baik dan benar serta disesuaikan dengan kompetensi dasar pada Sekolah Dasar. Teknik simak digunakan untuk memperoleh data yang dilakukan dengan menyimak penggunaan bahasa yang berupa wacana hasil tulisan siswa. Dalam arti, peneliti dalam upaya mendapatkan data dilakukan dengan menyadap penggunaan bahasa siswa yang menjadi informan (Mahsun, 2005:90). Adapun data bahasa yang disadap adalah data bahasa yang berupa kesalahan berbahasa siswa yang terdapat tulisan siswa yang meliputi kesalahan pemakaian ejaan, pemilihan kata, dan penyusunan kalimat. Teknik catat digunakan untuk mencatat hasil simakan berupa kesalahan berbahasa siswa yang sudah teridentifikasi. Penganalisisan data menggunakan prosedur analisis kesalahan berbahasa yang meliputi: (1) pengumpulan sampel, pengidentifikasian kesalahan yang terdapat dalam sampel, (3) penjelasan kesalahan, (4) pengklasifikasian kesalahan berdasarkan penyebabnya, dan (5) pengevaluasian atau penilaian taraf keseriusan kesalahan.

\section{HASIL PENELITIAN DAN PEMBAHASAN}

Hasil penelusuran terhadap beberapa jurnal penelitian tentang analisis kesalahan berbahasa Indonesia diperoleh bahwa terdapat kesalahan pemakaian ejaan, kesalahan pemilihan kata, dan kesalahan penyusunan kalimat dalam menulis. 
Untuk lebih jelasnya, dapat diuraikan sebagai berikut:

Kesalahan pemakaian ejaan yang ditemukan dalam penelitian ini meliputi:

a. Kesalahan penulisan kata dasar,

b. Kesalahan pemakaian huruf kapital

c. Kesalahan penulisan awalan

d. Kesalahan penulisan preposisi

e. Kesalahan penulisan singkatan

f. Kesalahan pemakaian tanda baca.

Kesalahan penulisan kata dasar ini terjadi jika siswa menuliskan kata yang tidak sesuai dengan bentuk sempurnanya yang terdapat dalam Kamus Besar Bahasa Indonesia (KBBI).

Beberapa kata yang banyak disingkat oleh siswa, padahal terhadap kata-kata tersebut seharusnya tidak dilakukan penyingkatan. Kata-kata yang dimaksud adalah yang, dengan, tidak, juga, jangan. Contoh sebagai berikut :

Dekat dg berbagai ....yg tak teratur Teman-teman jg jangan ... yg memiliki .... ...semoga warga di desa kita tdk melakukan hal ... disertai dgn pendidikan yg berkualitas...

Pelesapan vokal /o/ pada kata dasar terlihat pada kata karna dan trima yang seharusnya ditulis karena dan terima. Contohnya sebagai berikut:

Aku baru tau tadi pagi karna banyak tetanggaku ... Trima kasih va. Rud!
Konsonan /h/ yang dilafalkan secara tidak sempurna sering menimbulkan permasalahan dalam penulisan kata. Pelafalan konsonan $/ \mathrm{h} /$ seperti itu adalah jika konsonan $/ \mathrm{h} /$ diapit oleh dua vokal yang berbeda, misalnya /h/ diapit /a/ dan /u/ pada tahu.Selain itu, konsonan $/ \mathrm{h} /$ yang berposisi pada akhir suku kata, misalnya $/ \mathrm{h} /$ pada menuduh yang dilesapkan sehingga menjadi menudu dan pemunculan $/ \mathrm{h} /$ pada terimah yang seharusnya terima. Berikut contohnya:

Raihan ingin tau soal Aku tidak menudu, aku melihat sendiri ... kami

Huruf kapital dipakai sebagai huruf pertama unsur nama orang (Tim Pengembang Pedoman Bahasa Indonesia, 2016:5), nama bulan dan nama geografi (Tim Pengembang Pedoman Bahasa Indonesia, 2016:9). Akan tetapi, data penelitian menunjukkan adanya kesalahan penulisan tersebut. Perhatikan contoh berikut:

... sebuah kompleks pemakaman di medan, dan chairil memang segera ....

... sebagaimana kata Chairil anwar, ....Hai rafael apa kabar! Tanggal lahirnya, 26 juli 1992.

Huruf kapital dipakai huruf pertama awal kalimat (Tim Pengembang Pedoman Bahasa Indonesia, 2016:5). Ketentuan ini sering dilanggar siswa sehingga terjadi kesalahan penulisan huruf kapital. Datanya sebagai berikut: 
ada siswa yang baru ....
.. di majalah anak-anak.
ayah menjelaskan ....

... pulang dari sekolah.

Sebaliknya, huruf kapital sering dipakai di tengah kalimat sehingga menimbulkan kesalahan penulisan huruf kapital.

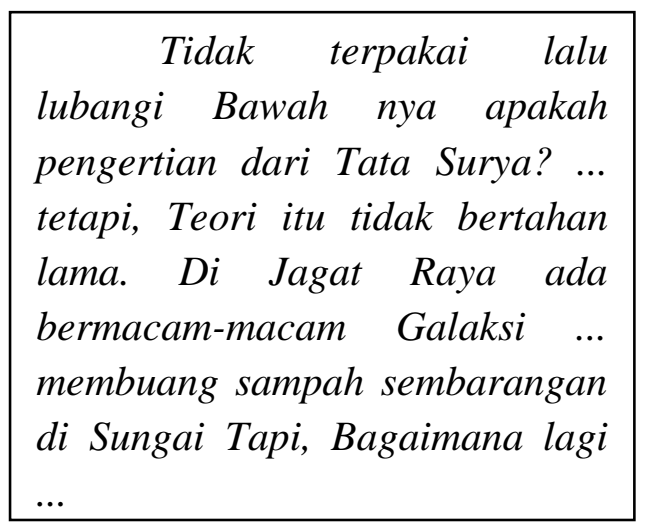

Bahkan tidak jarang huruf kapital dipakai di tengah kata seperti data berikut.

\begin{tabular}{|l|}
\hline Ruang AuLa 2 ... acara \\
perpisahan aNak-aNak kelas VI \\
... benda langit lain be Revolusi
\end{tabular}

Singkatan yang terdiri atas huruf awal setiap kata nama lembaga pemerintah dan ketatanegaraan, lembaga pendidikan, badan atau organisasi, serta nama dokumen resmi ditulis dengan huruf kapital tanpa tanda titik. Huruf kapital dipakai pada singkatan nama lembaga seperti pada singkatan SMP (Sekolah Menengah Pertama). Singkatan nama orang, gelar, sapaan, jabatan, atau pangkat diikuti dengan tanda titik pada setiap unsur singkatan itu (Tim Pengembang Pedoman Bahasa Indonesia, 2016:26). Pada singkatan yang berasal dari satu kata,hanya huruf awal yang ditulis dengan huruf kapital seperti pada singkatan Drs. (doktorandus). Singkatan pada data berikut menyalahi kaidah tersebut.

\begin{tabular}{|l|l|}
\hline \multicolumn{4}{|c|}{ Selesai juga tes smp dan } \\
UN ... DRS. Albert W.S. \\
Siswa/siswi Sdn 075621 medan.
\end{tabular}

benar adalah:

Penulisan singkatan yang \begin{tabular}{|llll|}
\hline \multicolumn{4}{|c|}{ Selesai juga tes SMP dan } \\
UN $\ldots$ & Drs. Albert W.S. \\
Siswa/siswi SDN 075621 Medan.
\end{tabular}

Imbuhan (awalan, sisipan, akhiran, serta gabungan awalan dan akhiran) ditulis serangkai dengan bentuk dasarnya (Tim Pengembang Pedoman Bahasa Indonesia, 2016:16). Penulisan awalan dipada data berikut tidak sesuai dengan aturan tersebut.

\begin{tabular}{|l|}
\hline \multicolumn{2}{|c|}{ Ceritanya telah di } \\
kisahkan kembali ... ibu bapak \\
Chairil menolak di panggil \\
"uda" ... ... tidak baik untuk di \\
konsumsi Acara tersebut akan di \\
selenggarakan pada \\
\hline
\end{tabular}

Penulisan awalan yang benar adalah:

Ceritanya telah dikisahkan kembali ... ibu bapak Chairil menolak dipanggil "uda” ... ... tidak baik untuk dikonsumsi Acara tersebut akan diselenggarakan pada

Kata depan, seperti di, ke, dan dari, ditulis terpisah dari kata yang mengikutinya (Tim Pengembang 
Marwan Pandeangan : Analisis Kesalahan Berbahasa ...

Pedoman Bahasa Indonesia, 2016:24).

Data berikut menyalahi kaidah tersebut.

Kebersihan ditempat itu belum tentu terjamin ... jajanan yg dijual dipinggir jalan itu .... Tentang kompas dimajalah anak-anak ... 1 $\mathrm{cm}$ kedalam wadah kemana kesana

Penulisan kata depan yang benar adalah:

Kebersihan di tempat itu belum tentu terjamin ... jajanan yg dijual di pinggir jalan itu .... Tentang kompas di majalah anak-anak ... $1 \mathrm{~cm}$ ke dalam wadah ke mana ke sana

Kesalahan pemakaian tanda
baca terlihat pada kesalahan pemakaian tanda hubung pada kata ulang, kesalahan pemakaian tanda intonasi final, tanda garis miring, dan tanda titik pada singkatan. Tanda Hubung pada Kata Ulang Tanda hubung dipakai untuk menyambung unsur kata ulang (Tim Pengembang Pedoman Bahasa Indonesia, 2016:47). Pemakaian tanda hubung di antara unsur-unsur kata ulang dilakukan tanpa spasi sebelum dan sesudahnya. Dalam penelitian ini banyak ditemukan adanya spasi sebelum dan sesudah tanda hubung di antara unsurunsur kata ulang seperti data berikut.

... juga dari sajak sajaknya tercatat .... Anak - anak sekolah akan berziarah ....
Tanda titik pada singkatansingkatan dalam bahasa Indonesia ada yang memakai tanda titik dan ada yang tanpa tanda titik. Singkatan yang memakai tanda titik adalah (1) singkatan nama orang, gelar, sapaan, jabatan, atau pangkat, (2) singkatan yang terdiri atas tiga huruf atau lebih, dan (3) singkatan yang terdiri atas dua huruf yang lazim dipakai dalam suratmenyurat. Singkatan yang tidak memakai tanda titik adalah: (1) Singkatan yang terdiri atas huruf awal setiap kata nama lembaga pemerintah dan ketatanegaraan, lembaga pendidikan, badan atau organisasi, serta nama dokumen resmi, (2) Singkatan yang terdiri atas huruf awal setiap kata yang bukan nama diri, dan (3) Lambang kimia, singkatan satuan ukuran, takaran, timbangan, dan mata uang (Tim Pengembang Pedoman Bahasa Indonesia, 2016:26-28). Penulisan singkatan berikut menyimpang dari kaidah di atas.

Yth : Kepala Sekolah SDN 075621 Medan

Penulisan singkatan tersebut seharusnya diubah menjadi seperti berikut:

\begin{tabular}{|l|}
\hline Yth. Kepala Sekolah SDN \\
075621 Medan \\
\hline
\end{tabular}

Kesalahan pemakaian ejaan yang ditemukan dalam penelitian ini senada dengan hasil penelitian lain. Penelitian Maulidia (2013:111) menyimpulkan beberapa kesalahan dalam karangan siswa MI meliputi kesalahan penulisan kata dasar, pemakaian huruf kapital, penulisan 
prefiks, penulisan preposisi, penulisan singkatan dan akronim, dan pemakaian tanda baca. Penelitian Hanafi (2012) menghasilkan beberapa temuan kesalahan berbahasa siswa yang meliputi kesalahan penggunaan huruf kapital, penggunaan tanda titik, penggunaan tanda koma, pemenggalan kata di akhir baris, serta penulisan kata terkait dengan awalan dan kata depan. Penelitian Anjarsari (2013:8) menunjukkan bahwa kesalahan pemakaian bahasa Indonesia penutur bahasa asing yang paling dominan adalah kesalahan ejaan (53,2\%). Kesalahan bidang lain berturut-turut sebagai berikut: kesalahan sintaktis $(21,10 \%)$, kesalahan morfologis $(20,4 \%)$, dan kesalahan semantis $(5,3 \%)$. Dengan demikian, ejaan merupakan bidang bahasa yang perlu mendapatkan perhatian.

\section{Pembahasan}

Kesalahan pemilihan kata paling banyak terlihat pada kesalahan penggunaan kata-kata tutur. Kata-kata tutur adalah kata-kata yang digunakan dalam pembicaraan santai seharihari.Kata-kata bercetak tebal berikut merupakan kata-kata tutur yang tidak boleh digunakan dalam situasi resmi. Kata-kata tutur lain yang ditemukan dalam tulisan siswa di antaranya ngerjain, sampe, gimana, udah, mikirin, enak'an, kalok, enggak, kayak, cuman dikit, maen, mumpung, nunggu.

Kesalahan

penyusunan

kalimat terjadi karena adanya kalimat tidak lengkap, kalimat tidak hemat, dan kalimat mengandung interferensi.

Kalimat lengkap adalah kalimat yang minimal terdiri atas subjek dan predikat, adanya objek dan pelengkap tergantung pada predikatnya. Kalimat yang tidak memenuhi ciri kalimat lengkap disebut kalimat tidak lengkap. Kalimat tidak lengkap dapat berupa: (1) kalimat tidak bersubjek, (2) kalimat tidak berpredikat, (3) kalimat tidak berobjek/tidak berpelengkap (Ghufron, 2015:159).

Kalimat tidak hemat atau kalimat yang mubazir adalah kalimat yang menggunakan dua bentuk bahasa yang maknanya sama. Ketidakhematan kalimat ini terjadi karena beberapa sebab: (1) penggunaan kata-kata yang maknanya sama, (2) penggunaan kata bentukan beserta maknanya, (3) penggunaan dua konjungsi yang semakna, dan (4) penggunaan subjek yang berlebihan. Interferensi adalah pengaruh bahasa lain yang bersifat mengganggu/merusak. Kalimat interferensi adalah kalimat yang terpengaruh oleh bahasa daerah atau bahasa asing. Pengaruh itu dapat berupa kosakata (interferensi leksikal) dan dapat berupa struktur (interferensi struktural): struktur kata atau struktur kalimat. Kata-kata yang ditemui adalah Kosakata yang dimaksud adalah ngelanjutin, kepengen, bener, ngerjain, gimana, ngapain, cuman, dikit, gak, kayak, mumpung, ngomelin. 


\section{SIMPULAN}

Berdasarkan uraian tentang hasil penelitian dapat dirumuskan beberapa simpulan sebagai berikut. Kesalahan berbahasa yang terdapat dalam tulisan siswa kelas Sekolah Dasar (SD) meliputi: kesalahan ejaan, kesalahan pemilihan kata, dan kesalahan penyusunan kalimat. Kesalahan pemakaian ejaan yang ditemukan dalam penelitian ini meliputi kesalahan: (1) penulisan kata dasar, (2) pemakaian huruf kapital, (3) penulisanawalan, (4) penulisan preposisi, (5) penulisan singkatan, dan (6) pemakaian tanda baca. Kesalahan penulisan kata dasar ini terjadi jika siswa menuliskan kata yang tidak sesuai dengan bentuk sempurnanya yang terdapat dalam Kamus Besar Bahasa Indonesia. Kesalahan penulisan kata dasar ini terlihat dalam tiga wujud: (1) penulisan singkatan kata yang seharusnya tidak disingkat, (2) pelesapan vokal (ə), serta (3) pelesapan dan pemunculan fonem $/ \mathrm{h} /$. Kesalahan pemakaian huruf kapital dalam penelitian ini terjadi pada kasus-kasus berikut: (1) penulisan nama, (2) penulisan awal dan tengah kalimat serta tengah kata, dan (3) singkatan. Kesalahan pemakaian tanda baca terlihat pada kesalahan pemakaian tanda hubung pada kata ulang, kesalahan pemakaian tanda intonasi final, tanda garis miring, dan tanda titik pada singkatan. Kesalahan pemilihan kata paling banyak terlihat pada kesalahan penggunaan kata-kata tutur. Kesalahan penyusunan kalimat terjadi karena adanya kalimat tidak lengkap, kalimat tidak hemat, dan kalimat interferensi.

\section{DAFTAR RUJUKAN}

Anjarsari, Nurvita dkk. 2013. Analisis Kesalahan Pemakaian Bahasa Indonesia dalam Karangan Mahasiswa Penutur Bahasa Asing di Universitas Sebelas Maret. Dalam BASASTRA: Jurnal Penelitian Bahasa, Sastra Indonesia, dan Pengajarannya Volume 2 Nomor 1, April 2013 hal. 1-14.

Brown, H. Douglas. 2000. Principles of Language Learning and Teaching (Fourth Edition). New Jersey: Addison Wesley Longman.

Farihah, M., \& Faisal, M. 2017. Learning Media Development Based on" Meme" as Efforts to Prevent Miscellanee Drug Abuse in Class VI of Elemtary School. In International Conference on Technology and Vocational Teachers (ICTVT 2017). Atlantis Press.

Faisal, S. P., \& Lova, S. M. 2018. Pembelajaran Tematik di Sekolah Dasar. Medan: Harapan Cerdas.

Faisal, F., \& Lova, S. M. 2018. The Development of Reading Learning Material Based on DRTA Strategy as an Effort to Build a Literate Generation in Fifth Grade (5th) of Primary School. School Education Journal PGSD FIP Unimed, 8(2), 145-158.

Faisal, F. 2018. Persepsi Mahasiswa PGSD Terhadap Implementasi 
KKNI di Universitas Negeri

Medan. Jurnal

Inovasi

Pendidikan dan Pembelajaran

Sekolah Dasar, 2(1).

Mailani, E. 2018. Potret Implementasi Pembelajaran

Berbasis High Order Thinking

Skills (Hots) Di Sekolah Dasar

Kota Medan. Jurnal

Pembangunan Perkotaan, 6(2), 102-111.

Faisal, F. 2019. Faktor-Faktor Yang Mempengaruhi Rendahnya

Partisipasi Anak Usia 4-6 Tahun

Terhadap Pendidikan Anak Usia

Dini Di Kota Medan. Jurnal

Pembangunan Perkotaan, 7(1), 65-72.

Faisal, F., Mailani, E., Ananda, L. J., \& Lova, S. M. 2019. Deskripsi Implementasi Penilaian Autentik Berbasis High Order Thinking Skills (Hots) Dalam Menjawab Tantangan Abad 21 Di Sekolah Dasar Kota Medan. Elementary School Journal PGSD Fip Unimed, 9(2), 126-132.

Ghufron, Syamsul. 2015. Kesalahan Berbahasa: Teori dan Aplikasi. Yogyakarta: Ombak.

Hanafi, Iduar. 2012. Analisis Kesalahan Penggunaan Ejaan Bahasa Indonesia Siswa Kelas V pada Revisi Karangan Narasi di Sekolah Dasar Kecamatan Pulau Laut Utara, Kotabaru Kalimantan Selatan. Tesis. Yogyakarta: Program Pascasarjana, Universitas Negeri Yogyakarta.

Maulidia, Eva Nur. 2013. Kesalahan Pemakaian Ejaan dalam
Karangan Siswa Kelas V MI Thoriqotul Hidayah 2 Pilang, Laren, Lamongan. Skripsi Tidak Dipublikasikan. Lamongan: Universitas Islam Darul Ulum Lamongan.

Nurgiyantoro, Burhan. 2010. Penilaian Pembelajaran Bahasa Berbasis Kompetensi.

Yogyakarta: BPFE-Yogyakarta.

Sumardi. 2000. Panduan Penelitian,

Pemilihan, dan Penyusunan:

Buku Pelajaran Bahasa

Indonesia SD Sebagai Sarana Pengembangan Kepribadian,

Penalaran, Kreativitas, dan

Keterampilan Berkomunikasi

Anak. Jakarta: PT Grasindo.

Suparnis. 2007. Pembelajaran Gramatika Bahasa Indonesia

Berdasarkan Pendekatan

Komunikatif di SMP Negeri 2

Kota Bengkulu: Studi Kasus.

Tesis tidak diterbitkan. Malang:

Universitas Negeri Malang.

Tim Pengembang Pedoman Bahasa Indonesia. 2016. Pedoman Umum Ejaan Bahasa Indonesia. Jakarta: Badan Pengembangan dan Pembinaan Bahasa, Kementerian Pendidikan dan Kebudayaan. 